\title{
反科学ティーパーティー運動に要注意
}

\section{Science scorned}

2010 年 9 月 9 日号 Vol. 467 (133)

経済的苦境にある米国で、保守派の間に反科学的傾向が広がっている。その典型がティーパーティー運動だ。 それでも、大多数の米国民は科学に対して強い信頼感を寄せている。

「この世界には、政府、大学、科学、メ ディアという四大欺瞞・ペテンが存在 しています。阷落したこれら 4 機関は、 まさにその欺瞞性ゆえに存在していま す。それはまた彼らが存在を誇示する やり口であり、彼らが繁栄している理 由でもあるのです」。この過激な発言は、 米国の保守派ラジオ番組の司会者 Rush Limbaugh によるものだ。こんな発言や 言葉のまやかしに満ちた放送内容など 一笑に付したいところだが、Limbaugh や同類の意見は、笑い事ですますことは できない。

米国の保守派は反科学的傾向を強め ており、その社会的・政治的影響力が、 環境問題や幹細胞研究など、数多くの 方面で目に見える形で現れる可能性が ある。

例えば 9 月初め、アラスカ州におけ る上院中間選挙（11月2日）に向け た共和党の予備選挙が行われ、現職の Lisa Murkowski 議員が、政治的に無 名の Joe Miller 候補に敗れる大波乱が あった。Miller 候補は保守的な「ティー パーティー運動」の支援を受けており、 Murkowski 議員が地球温暖化の現実を 認めたことが、「彼女の交代が必要なこ とを示す最重要証拠物件だ」と断じた。

経済的に不安定な状沉にある現在の 米国に拀いて、保守派ポピュリズムが 勢いを増している。彼らの多くは、反 増税、反規制、反移民といった伝統的 な保守派の主張をそのまま唱えている。 しかし、ティーパーティー運動とその 応援団は、エリートや専門家に対する
疑念という、米国民の昔ながらの政治 的衝動をうまく利用している。この応 援団には、Limbaugh をはじめ、Fox News 社のテレビ番組の司会者 Glenn Beck、ショウジョウバエの研究を公的 資金の無駄遣いと非難したことで有名 な Sarah Palin らが名を連ねている。

地球温暖化への過激な否定は、ティー パーティー運動が科学に対していかな る姿勢を取っているか、世間にはっき りと見せつける事件となった。例えば Limbaugh は、自分の番組で、「科学 は、居場所のなくなった社会主義者と 共産主義者の活動拠点となった」と語 り、気候変動科学を「史上最大のペテン」 とよんだ。

ティーパーティー運動はまた、ダー ウィン的進化論、幹細胞研究、胚研究に 対する宗教的反感という傾向を持ち合 わせている。とりわけ Beck は、こうし た研究を優生学思想と同一視している。

ティーパーティー運動は、科学的根 拠に基づいた規制に対しても、政府が 国民生活に立ち入るための言い訳とと らえており、嫌悪感を隠さない。

ブッシュ政権下における米国の科学 政策は、軽視とイデオロギーという 2 つの面で困難に直面した。そこで「科 学を正当な地位に戻す」というのがオ バマ大統領の公約なのだが、「科学＝リ ベラル」という図式を人々に与えてし まったようで、保守派の格好の標的と なっているわけだ。

米国民が直面している経済問題は、 まさに現実のものである。
中国やその他の新興科学大国との競 争が激化する中で、米国の将来は、教育、 科学、技術に極めて大きな比重がかかっ ている。8月にはサルモネラ中毒のおそ れから数億個の米国産舀卵が回収され た。また 4 月にはディープウォーター・ ホライズンの原油流出事故も発生した が、こうした出来事は、米国政府に、科 学に基づいた、より優れた規則を制定・ 実施し、国民のために行動する必要性 を思い起こさせるよい機会となった。

しかし、米国民は、企業や企業が後 援するシンクタンクや偽装団体が画策 した反科学・反規制の行動計画を、単 純に受け入れてしまうことが多いのも また現実なのだ。

現在のような敵意に満ちた政治的雾 囲気の中では、科学の擁護者が取りう る対処法は限られている。しかし心強 いことに、世論調査では、圧倒的多数 の米国民が、科学は世のため人のため になる力だと引き続き考えており、現 在の科学に対する不平不満は一時的な ものと考えられる。科学者は、教育者 として、若い人々に合理主義、学問、 批判的思考を奨励し、また、メディア や政治家とも手を携えて、現代の契緊 の科学的課題を明らかにするために一 層の努力を払うべきである。

(翻訳 : 菊川要) 